ISSN 2080-1653

\author{
JOANNA DOMINIAK \\ Uniwersytet im. Adama Mickiewicza w Poznaniu, Polska \\ Adam Mickiewicz University in Poznań, Poland
}

\title{
Nowoczesne usługi a poziom rozwoju gospodarczego
}

\section{Modern Services and the Level of Economic Development}

\begin{abstract}
Streszczenie: Działalność usługowa, będąca ważną częścią współczesnej gospodarki, nieustannie podlega zmianom. Zmiany te są uwarunkowane procesami ekonomicznymi, które wynikają m.in. z postępu technologicznego, nasilającej się globalizacji i zwiększającej się konkurencyjności. Zgodnie z teoriami działalności usługowej, coraz większego znaczenia nabierają usługi wyspecjalizowane, w których zatrudniani są pracownicy o wysokich kwalifikacjach zawodowych. Do tych usług należą dynamicznie rozwijające się usługi o wysokim nasyceniu wiedzą. Na rozwój usług wyspecjalizowanych wpłynął także wzrost zapotrzebowania na nowoczesne usługi w dobie rozwoju gospodarki opartej na wiedzy. Zmiany zachodzące w strukturze usług są ściśle związane z procesem rozwoju społeczno-gospodarczego. W procesie rozwoju społeczno-gospodarczego, według Flejterskiego, Panasiuka, Perenca i Rosy (2005), wyróżnia się cztery fazy rozwoju sektora usług: (1) fazę pierwotną charakteryzującą się dominacją usług, które nie wymagają wysokich kwalifikacji, (2) fazę wzrostową, która cechuje się rozwojem usług wymagających pewnych kwalifikacji, (3) fazę obsługi przemysłu i wzrostu konsumpcji usług oraz (4) fazę rozwoju usług opartych na wysokich technologiach. Nowoczesne usługi oparte na wiedzy odgrywają ważną rolę w rozwoju gospodarczym. Celem artykułu jest próba przybliżenia kwestii terminologicznych związanych z usługami nowoczesnymi oraz próba odpowiedzi na pytanie o ich rolę w rozwoju nowoczesnych gospodarek.
\end{abstract}

Abstract: Service activities which are an essential part of the modern economy have constantly been changing. These changes are conditioned by economic processes that are a consequence of technological progress, the growing process of globalization and increasing competitiveness. According to the theories of services, specialized services, employing staff with high professional qualifications, including dynamically developing knowledge intensive services are becoming increasingly important. Their development also contributed to an increase in demand for modern services in the knowledge-based economy. Changes in the structure of services are closely related to the process of socio-economic development. In the said process, according to Flejterski et al. (2005), there are four phases of development of the services sector: (1) primary phase characterized by the dominance of services that do not require high qualifications, (2) growth phase which is characterized by the development of services requiring certain qualifications, (3) phase of industry operation and the growth in consumption of services and (4) phase of the development of services based on high technologies. Modern knowledge-based services play an important role in economic development. The article attempts to develop the issue of terminology related to modern services and to answer the question about their role in the development of modern economies.

Słowa kluczowe: innowacyjność; rozwój społeczno-gospodarczy; usługi; usługi nowoczesne Keywords: innovativeness, modern services; services; socio-economic development

Otrzymano: 17 grudnia 2016

Received: 17 December 2016

Zaakceptowano: 12 luty 2017

Accepted: 12 February 2017 
Sugerowana cytacja / Suggested citation:

Dominiak, J. (2017). Nowoczesne usługi a poziom rozwoju gospodarczego. Prace Komisji Geografii Przemysłu Polskiego Towarzystwa Geograficznego, 31(1), 81-96.

\section{WSTĘP}

W tradycyjnym ujęciu poziom rozwoju usług ma duży wpływ na poziom rozwoju społeczno-gospodarczego. Sektor usług przyczynia się do rozwoju społeczno-gospodarczego kraju i regionów poprzez tworzenie nowych miejsc pracy, wzrost dochodu i zaspokojenie potrzeb mieszkańców (Illeris, 1996). Wraz z przemianami zachodzącymi we współczesnych gospodarkach zmianie ulega także rola usług. Zmiany te są uwarunkowane procesami ekonomicznymi, będącymi skutkiem m.in. postępu technologicznego, nasilającej się globalizacji i zwiększającej się konkurencyjności. Zgodnie z teoriami działalności usługowej coraz większego znaczenia nabierają usługi wyspecjalizowane, w których zatrudniani są pracownicy o wysokich kwalifikacjach zawodowych. Do tych usług należą dynamicznie rozwijające się usługi o wysokim nasyceniu wiedzą. Usługi wyspecjalizowane, nazywane usługami nowoczesnymi, nabierają kluczowego znaczenia w procesie rozwoju współczesnej gospodarki.

Celem artykułu jest: (1) identyfikacja nowoczesnych usług w świetle literatury przedmiotu, (2) próba konstrukcji modelu wpływu nowoczesnych usług na rozwój gospodarczy, (3) analiza poziomu rozwoju nowoczesnych usług w układzie państw UE oraz (4) empiryczna weryfikacja modelu wpływu nowoczesnych usług na rozwój gospodarczy w układzie państw UE. Analiza empiryczna została przeprowadzona przy wykorzystaniu danych statystycznych z bazy Eurostatu.

\section{USŁUGI NOWOCZESNE I ICH ROLA W ROZWOJU W ŚWIETLE LITERATURY PRZEDMIOTU}

Podział na usługi tradycyjne i nowoczesne ma związek z podatnością na postęp technologiczny. Jednym z pierwszych podziałów na usługi nowe, stare i komplementarne był podział zaproponowany przez Katouziana (1970). Wiązał on usługi nowe i komplementarne z rozwojem gospodarczym oraz z postępującą industrializacją. Do usług nowych zaliczył on usługi związane z edukacją, wypoczynkiem oraz ochroną zdrowia, natomiast do komplementarnych: administrację, transport, finanse, handel. Ich wspólną cechą jest skokowy charakter wzrostu uzależniony od rozwoju techniki (Ilnicki, 2009). Zmiany, jakie zaszły w sposobie organizacji i form świadczenia usług, spowodowały jednak, że podział ten nie do końca przystaje do rzeczywistości. „Wzajemne przenikanie się usług nowych i komplementarnych w podejściu tradycyjnym można wyeliminować poprzez traktowanie usług nowych jako rodzajów działalności nowych, związanych z postępem technicznym i technologicznym, o wysokiej dynamice wzrostu, a dodatkowo $\mathrm{w}$ początkowym okresie mających w większym stopniu charakter usług ponadpodstawowych" (Jakubowicz, 2000; Ilnicki, 2009: 53). W celu odróżnienia od tradycyjnego podejścia używa się także terminu: usługi nowoczesne, jednak sens ich pozostał niezmienny. Usługi nowoczesne traktuje się zwykle jako usługi wyższego rzędu, podatne na postęp techniczny, oparte i bazujące na wiedzy, dla rozwoju których niezbędne są wysokie kwalifikacje i/lub inwestycje w nowoczesne technologie. 
W klasyfikacji usług na tradycyjne i nowoczesne często pojawia się także kryterium dynamiki wzrostu udziału usług w tworzeniu PKB. Przykładem tego typu podejścia jest klasyfikacja Eichengreena i Gupty (2009). Wyróżniają oni:

- usługi tradycyjne (handel, transport i magazynowanie, administracja), których udział w tworzeniu PKB spada,

- usługi stanowiące hybrydę usług nowoczesnych i tradycyjnych (edukacja, opieka zdrowotna, hotele i restauracje, usługi komunalne i osobiste) - ich udział w tworzeniu PKB powoli rośnie,

- usługi nowoczesne (pośrednictwo finansowe, informatyka, usługi dla biznesu, komunikacja), których udział w tworzeniu PKB wzrasta bardzo dynamicznie.

Przegląd literatury przedmiotu prowadzi więc do wniosku, że drugim - obok podatności na postęp technologiczny - przyjętym kryterium wyróżniającym usługi nowoczesne jest ich dynamiczny rozwój. Nakładając na siebie te dwa kryteria, dokonano identyfikacji nowoczesnych usług, które zostaną poddane szczegółowej analizie w dalszej części opracowania. Do usług nowoczesnych zalicza się więc takie usługi, które spełniają dwa kryteria. Pierwsze kryterium wskazuje, że są to usługi należące do grupy tzw. usług opartych na wiedzy (KIS). Przyjęcie tego założenia ma tę zaletę, że usługi te występują w oficjalnych klasyfikacjach działalności (NACE, PKD), dzięki czemu możliwe jest pozyskanie danych statystycznych niezbędnych do analizy. Drugim przyjętym kryterium wyróżniającym usługi nowoczesne jest ich dynamiczny rozwój, wyrażający się wzrostem ich udziału w strukturze usług według miernika zatrudnienia.

Nałożenie na siebie tych dwóch kryteriów pozwala na wyróżnienie siedmiu rodzajów działalności usługowych, które zostaną poddane szczegółowej analizie w dalszej części opracowania. Należą do nich: usługi informatyczne, badawczo-rozwojowe, obsługa nieruchomości, usługi profesjonalne, finansowo-ubezpieczeniowe, edukacyjne i medyczne (tab. 1). Tego typu podejście ma podstawową zaletę - pozwala na prowadzenie analiz empirycznych w oparciu o publikowane dane statystyczne.

Tab. 1. Identyfikacja nowoczesnych usług w oparciu o dwa kryteria

\begin{tabular}{|c|c|c|}
\hline & $\begin{array}{c}\text { kryterium } 1 \\
\text { (usługi o wysokim } \\
\text { nasyceniu wiedzą; } \\
\text { knowledge intensive } \\
\text { services - KIS) }\end{array}$ & $\begin{array}{c}\text { kryterium } 2 \\
\text { (usługi cechujące się } \\
\text { wzrostem udziału } \\
\text { w strukturze usług według } \\
\text { miernika zatrudnienia) }\end{array}$ \\
\hline Działalność pocztowa i telekomunikacyjna & $\mathrm{V}$ & - \\
\hline Informatyka i działalność pokrewna & $\mathrm{V}$ & $\mathrm{V}$ \\
\hline Działalność badawczo-rozwojowa & $\mathrm{V}$ & $\mathrm{V}$ \\
\hline Transport wodny i powietrzny & $\mathrm{V}$ & - \\
\hline Obsługa nieruchomości & $\mathrm{V}$ & $\mathrm{V}$ \\
\hline Usługi profesjonalne & $\mathrm{V}$ & $\mathrm{V}$ \\
\hline Pośrednictwo finansowe i ubezpieczenia & $\mathrm{V}$ & $\mathrm{V}$ \\
\hline Edukacja & $\mathrm{V}$ & $\mathrm{V}$ \\
\hline Opieka zdrowotna & $\mathrm{V}$ & $\mathrm{V}$ \\
\hline Działalność sportowa, kulturalna i rekreacyjna & $\mathrm{V}$ & - \\
\hline
\end{tabular}

Źródło: opracowanie własne 


\section{MODEL WPŁYWU NOWOCZESNYCH USŁUG NA ROZWÓJ}

Usługi nowoczesne odgrywają ważną rolę w rozwoju społeczno-gospodarczym w dobie gospodarki opartej na wiedzy. We współczesnej gospodarce główną siłą napędową rozwoju jest tworzenie i umiejętne wykorzystywanie wiedzy, stąd wśród czynników i uwarunkowań rozwoju tak duże znaczenie mają kapitał ludzki (ze względu na fakt, że wiedza ucieleśniona jest w człowieku) i kapitał społeczny (który odgrywa ważną rolę w procesie przepływu i dyfuzji wiedzy oraz innowacji). Wiedza zawsze była istotna dla rozwoju, ale współcześnie stanowi ważne narzędzie zwiększania poziomu innowacyjności oraz najważniejsze źródło przewagi konkurencyjnej. Przegląd literatury przedmiotu prowadzi do wniosku, że wśród najistotniejszych czynników rozwoju należy wymienić: (1) kapitał ludzki, stanowiący źródło i ważne ogniwo przepływu wiedzy do gospodarki (Chojnicki, Czyż, 2003), (2) kapitał społeczny (klimat społeczny), odgrywający zasadniczą rolę w procesie przepływu wiedzy i w procesie wspólnego uczenia się, (3) środowisko innowacyjne, które poprzez generowanie i transfer innowacji warunkuje działalność innowacyjną, (4) obsługę biznesu wspierającą funkcjonowanie nowoczesnych przedsiębiorstw na rynku (usługi profesjonalne) oraz (5) kapitał finansowy pozwalający na finansowanie działalności innowacyjnej.

\section{Kapitał ludzki}

Postęp techniczny jest efektem akumulacji wiedzy technicznej. Sam jednak dostęp do wiedzy nie jest czynnikiem wystarczającym do uaktywnienia procesów rozwojowych. Niezbędna jest bowiem umiejętność jej absorpcji w praktyce gospodarczej. To właśnie kapitał ludzki stanowi zasadniczy czynnik wpływający zarówno na proces akumulacji wiedzy, jak i jej absorpcję przez gospodarkę. Kapitał ludzki stanowi więc źródło i jednocześnie potencjalne ogniwo przekazywania wiedzy do gospodarki.

Pojęcie kapitału ludzkiego wprowadził do teorii ekonomii T. Schultz w latach sześćdziesiątych XX wieku. Pod pojęciem kapitału ludzkiego rozumiał cechy populacji, które mają wartość i mogą być wzbogacane za pomocą odpowiedniego inwestowania. Kapitał ludzki jest ucieleśniony w człowieku i jest z nim nierozerwalnie związany. Najczęściej jest definiowany jako wiedza, umiejętności, kompetencje oraz inne cechy człowieka powiązane z jego ekonomiczną aktywnością, np. zasoby zdrowia i energii witalnej (Domański, 1993), zasoby psychologiczne: odporność na stres, wiara w siebie, poczucie własnej wartości (Komorowski, 2010). Według Chojnickiego i Czyż (2006: 15) kapitał ludzki można ujmować dwojako: w wymiarze wartościowo-finansowym, co odpowiada rozumieniu kapitału ludzkiego w ujęciu wąskim (ocena poziomu wykształcenia, kompetencji obywateli) oraz w wymiarze społeczno-demograficznym, co odpowiada analizie kapitału ludzkiego w ujęciu szerokim (zasoby wiedzy, poziom zdrowia poszczególnych osób i całego społeczeństwa).

Pierwszy wymiar jest jednak trudny do oceny, stąd w analizie najczęściej stosuje się ujęcie społeczno-demograficzne. Wytwarzanie kapitału ludzkiego następuje na skutek edukacji, kształcenia i podnoszenia kwalifikacji osób zatrudnionych w gospodarce. Z tego względu kapitał ludzki analizuje się najczęściej na podstawie następujących cech: poziomu wykształcenia, aktywności zawodowej i obciążenia demograficznego. Ilość kapitału ludzkiego zależy od sytuacji demograficznej kraju, a zwłaszcza od liczby osób czynnych zawodowo. Natomiast jego jakość zależy od wykształcenia, doświadczenia i umiejętności. 


\section{Kapitał społeczny (klimat społeczny)}

Kapitał społeczny to według Fukuyamy (1999) skonkretyzowane nieformalne normy, które sprzyjają współpracy pomiędzy dwoma lub więcej jednostkami. Fukuyama zwraca jednak uwagę na to, że nie każdy zestaw skonkretyzowanych norm tworzy kapitał społeczny. Normy te musza prowadzić do współpracy w grupie, dlatego muszą być związane z takimi cechami, jak: szczerość, dotrzymywanie zobowiązań, rzetelne wypełnianie obowiązków, wzajemność itp.

W literaturze przedmiotu kapitał społeczny jest najczęściej definiowany jako umiejętność współpracy międzyludzkiej w obrębie grup i organizacji w celu realizacji wspólnych interesów. Umiejętność ta wynika z zaufania, norm społecznych, sieci i organizacji społecznych umożliwiających skoordynowane działania (Coleman, 1990). Założenie związane z koncepcją kapitału społecznego opiera się na inwestycji w relacje społeczne, która ma przynieść spodziewane zyski (Lin, 2001). Zwraca się uwagę na znaczenie takich cech, jak: sieci, zaufanie, wzajemność, normy (Baron, Field, Schuller, 2000; Stone, Hughes 2000). O kapitale społecznym decyduje infrastruktura, współdziałanie i koordynacja zachowań ludzkich. Formalne i nieformalne powiązania między ludźmi stymulują współpracę, podnoszą wydajność istniejących zasobów. Putnam (1993) wymienia następujące składniki kapitału społecznego: poziome więzi stowarzyszeniowe, normy społeczne, a zwłaszcza normy wzajemności oraz zaufanie.

Najważniejsza wartość kapitału społecznego polega na tym, że pozwala on na łączenie i efektywne wykorzystywanie pozostałych typów kapitału. Odgrywa on istotną rolę w przepływie wiedzy i innowacji. Jego znaczenie wzrasta jeszcze bardziej w dobie gospodarki opartej na wiedzy, w której kluczowe znaczenie ma efektywne tworzenie i wykorzystywanie wiedzy.

\section{3. Środowisko innowacyjne}

Współcześnie coraz częściej wskazuje się na konieczność uwzględnienia zarówno wiedzy, jak i innowacji w kształtowaniu zróżnicowania rozwoju gospodarczego w regionach. Można tu wymienić m.in. prace: Druckera (1993), Lundvalla, Johnsona (1994), Pavitta (2005), Freemana, Soete (2009). Freeman oraz Lundvall byli współtwórcami koncepcji systemu innowacji, w którym innowacje nie powstają wyłącznie dzięki wewnętrznym siłom firm, ale przy znaczącym udziale środowiska innowacyjnego (Piech, 2009). Środowisko innowacyjne, rozumiane jako zbiór ośrodków innowacyjnych wraz ze skupiskami innowacyjnych firm, określane jest w literaturze światowej przez Aydalota i Keeble'a, (1988) jako innovative milieu. Jest to lokalne skupisko firm zaawansowanej technologii (high-tech) oraz instytucji badawczo-rozwojowych (B + R), między którymi występują formalne i nieformalne powiązania. Powiązania te polegają na wymianie wysoko wykwalifikowanych pracowników między firmami, uniwersytetami i jednostkami badawczo-rozwojowymi oraz na współpracy między producentami, dostawcami i odbiorcami (Dominiak, 2006). W środowisku innowacyjnym sieć relacji pomiędzy instytucjami innowacyjnymi oraz ich wzajemna współpraca generują dalszy rozwój innowacji i prowadzą do integracji środowiska innowacyjnego (Jewtuchowicz, 1996). Pietrzyk (2001: 49) za GREMI ${ }^{1}$ wymienia trzy podstawowe cechy charakterystyczne dla

${ }^{1}$ GREMI - Groupe de Recherche Europeen sur les Milieux Innovateurs (Europejski Zespół Badawczy nad Środowiskami Innowacyjnymi). 
tak definiowanego środowiska innowacyjnego: jego ramy terytorialne, właściwą mu logikę organizacyjną oraz dynamikę uczenia się: „W analizie środowiska innowacyjnego akcent zostaje położony na jego organizację i różnorodne więzi współpracy między przedsiębiorstwami, klientami, dostawcami, ośrodkami badawczymi, kształcenia itd. oraz zachodzące między nimi interakcje, poprzez które rozwijane są specyficzne kompetencje, wiedza, normy zachowań itp.". Środowisko innowacyjne poprzez bezpośredni wpływ na wzrost innowacyjności odgrywa ważną rolę w kształtowaniu się regionów wzrostu. Co więcej, może także pełnić istotną funkcję dyfuzora innowacji i przenosić je do pozostałych regionów.

Problematyka wpływu innowacyjności na zróżnicowanie poziomu rozwoju społeczno-gospodarczego regionów jest szczególnie istotna w dobie rozwoju gospodarki opartej na wiedzy. To dzięki właściwie wykształconemu środowisku innowacyjnemu możliwy jest etap generowania innowacji w ośrodkach sfery badawczo-rozwojowej i na uczelniach wyższych oraz etap ich komercjalizacji przy wsparciu centrów transferu technologii i innowacyjności. Sama infrastruktura badawczo-rozwojowa oraz instytucje innowacyjne zwykle nie są warunkiem wystarczającym dla rozwoju innowacyjności w regionie. Dopiero połączenie nauki i gospodarki ma kluczowe znaczenie dla efektywnego rozwoju innowacyjności danego regionu.

\section{Usługi profesjonalne (dla biznesu)}

Ważnym czynnikiem rozwoju nowoczesnej gospodarki stały się także usługi profesjonalne, zwane także usługami dla biznesu. Wzrost zainteresowania usługami dla biznesu $\mathrm{w}$ badaniach naukowych nastąpił na początku lat osiemdziesiątych. Było to związane częściowo z dynamicznym rozwojem i rosnącym znaczeniem tych usług w gospodarce postfordowskiej (Illeris, 1996). W latach osiemdziesiątych i dziewięćdziesiątych rozwinęły się koncepcje dotyczące roli tych usług w nowoczesnej gospodarce. Według Coffeya (2000), główne aspekty wpływu tego rodzaju usług na rozwój społeczno-gospodarczy przedstawiają się następująco. Po pierwsze, dynamiczny rozwój tego sektora usług powoduje powstawanie dużej liczby nowych miejsc pracy. Po drugie, usługi dla producentów i dla biznesu mają duży udział w eksporcie usług, przyczyniając się do wzrostu gospodarczego regionu. Usprawnienia w komunikacji i telekomunikacji osłabiły znaczenie bliskości przestrzennej usługodawcy i usługobiorcy, szczególnie w przypadku sektora usług dla producentów i biznesu, który około 30\% swoich usług świadczy poza miejscem lokalizacji (Illeris, 1996). Po trzecie, usługi dla producentów i biznesu odgrywają ważną rolę w rozwoju społeczno-gospodarczym poprzez wspomaganie elastycznej produkcji. Firmy coraz częściej rezygnują z utrzymywania w strukturze organizacyjnej wydziałów odpowiedzialnych np. za obsługę prawną czy serwis informatyczny i korzystają z usług wyspecjalizowanych firm zewnętrznych (zjawisko outsourcingu). Dzięki temu mogą szybko reagować na zmiany zachodzące na rynku, bez konieczności zwiększania lub zmniejszania zasobów pracy.

Pojęcie „usługi dla biznesu” (business services) rozumiane jest zarówno szeroko (i w tym znaczeniu bliższe jest pojęciu otoczenia biznesu), jak i wąsko - wówczas obejmuje następujące rodzaje usług: obsługa prawna, doradztwo podatkowe, doradztwo techniczne i gospodarcze oraz reklama i badanie rynku. 


\section{Kapitał finansowy}

Kapitał finansowy jest tradycyjnym rodzajem kapitału niezbędnym w procesie rozwoju gospodarczego. W teorii klasycznej ekonomii kapitał, rozumiany jako dobra finansowe i materialne, był jednym z trzech (obok ziemi i pracy) głównych czynników produkcji. Dopiero XX wiek przyniósł zmianę tego podejścia. Choć dodawano kolejne czynniki, którym w nowych teoriach rozwoju przypisywano coraz ważniejszą rolę, jak choćby kapitał ludzki i kapitał społeczny, to ciągle jeszcze kapitał finansowy ma ogromne znaczenie w procesach rozwojowych. „Obejmuje on całość środków finansowych, które mogą być przeznaczone na realizację nowych inwestycji powiększających kapitał materialny regionu oraz środki przeznaczane przez mieszkańców na konsumpcję zwiększającą popyt wewnętrzny" (Churski, 2008: 69). Kapitał finansowy, niezbędny w każdego rodzaju inwestycjach, w przypadku rozwoju działalności innowacyjnej nabiera jeszcze większej wagi. Badania dowodzą, że kapitał finansowy stanowi jeden z podstawowych determinantów rozwoju innowacyjności w polskich regionach (Dominiak, Churski, 2012).

Zestawienie wymienionych czynników rozwoju nowoczesnej gospodarki, a także wcześniejszych ustaleń związanych z nowoczesnymi usługami, doprowadziło do próby skonstruowania modelu wpływu nowoczesnych usług na proces rozwoju gospodarki opartej na wiedzy (ryc. 1). Model ten powstał w wyniku nałożenia na siebie uwarunkowań i czynników współczesnego rozwoju: kapitału ludzkiego, środowiska innowacyjnego, infrastruktury obsługi biznesu, kapitału finansowego i klimatu gospodarczego oraz wyróżnionych nowoczesnych usług, do których zaliczono: usługi badawczo-rozwojowe, usługi edukacyjne i medyczne, usługi profesjonalne (dla biznesu), usługi finansowe i usługi administracyjne.

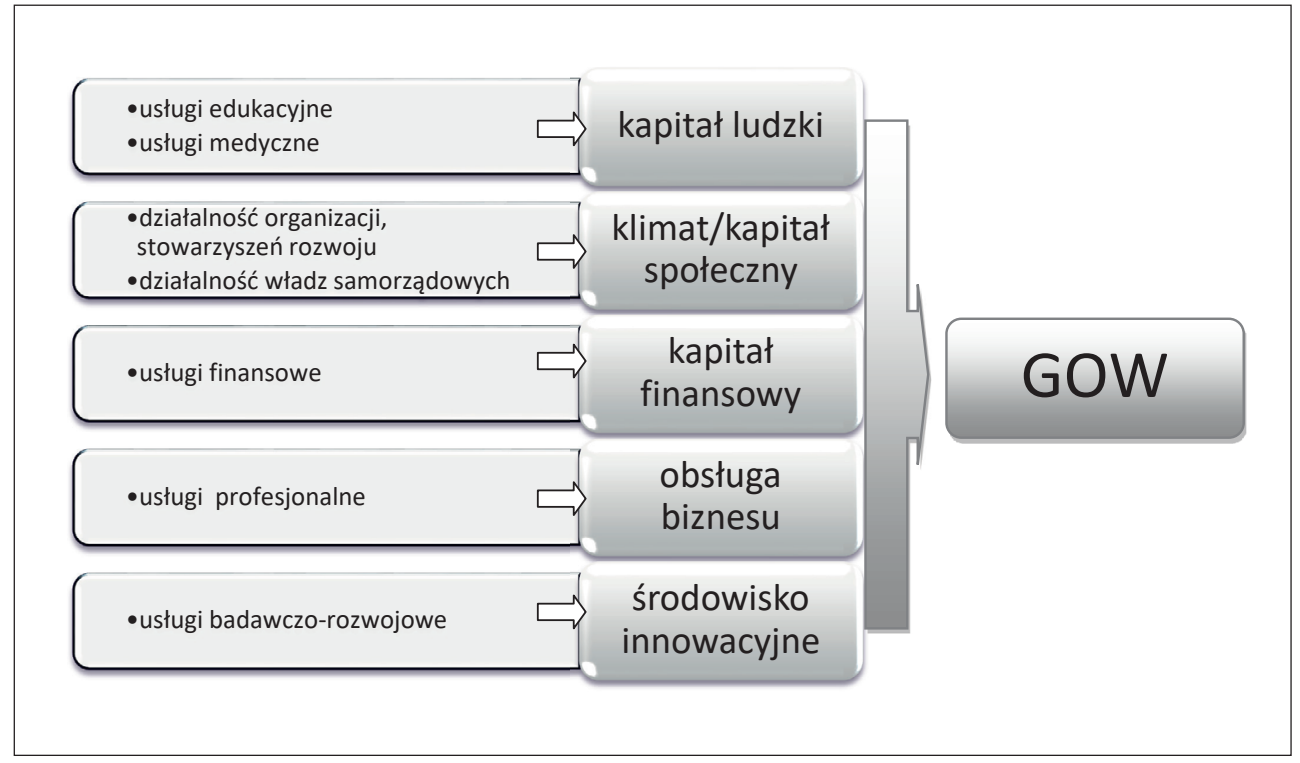

Źródło: opracowanie własne 
Zgodnie z tym modelem, wpływ nowoczesnych usług na gospodarkę opartą na wiedzy można sprowadzić do następujących relacji:

- usługi B + R oraz infrastruktura wspierająca innowacje

- generowanie innowacji (patenty, innowacje technologiczne i organizacyjne)

- transfer innowacji do gospodarki (centra innowacji)

(np. Aydalot, Keeble, 1988; Capello, Nijkamp, 2009; Uppenberg, 2009)

- usługi edukacyjne i medyczne

- kształtowanie kapitału ludzkiego w sferze kształtowania kwalifikacji i umiejętności - kształcenie kadr (szkoły wyższe) i kształcenie ustawiczne (szkolenia)

(np. Camagni, 1991; Becker, 1993; Lundvall, 2000; Chojnicki, Czyż, 2006; Markowski, Drzazga, 2008)

- działalność władz samorządowych

- kształtowanie odpowiedniego klimatu dla rozwoju nowoczesnej gospodarki

(np. Archibugi, Howells, Michie, 1999; Feldman, Link, 2001; Fagerberg, Mowery, Nelson, 2006; Colombo, Grilli, Piscitello, Rossi-Lamastra, 2011)

- usługi profesjonalne (dla biznesu)

- tworzenie infrastruktury wpierającej rozwój nowoczesnej gospodarki - usługi dla biznesu (działalność ośrodków doradczych, informacyjnych, obsługa podatkowa, prawna itp.)

- organizacje wspierające przedsiębiorczość

(np. Werwicki, 1998; Keeble, Lawson, Moore, Wilkinson, 1999; Longhi, 1999; Kłosiński, 2000)

- działalność finansowa

- obsługa finansowa (banki)

- wsparcie finansowe (fundusze pożyczkowo-poręczeniowe itp.)

(np. Berger, Udell, 2002).

Podstawowe znaczenie w kształtowaniu właściwego środowiska innowacyjnego, w kontekście analizowanego wpływu na rozwój nowoczesnej gospodarki, będą miały usługi sfery badawczo-rozwojowej, których podstawowym zadaniem jest generowanie innowacji, oraz usługi różnego rodzaju instytucji pośredniczących w transferze tych innowacji do sfery gospodarki, czyli ich komercjalizacji. Kapitał ludzki, będący kluczowym czynnikiem rozwoju gospodarki opartej na wiedzy, rozpatruje się z punktu widzenia roli usług edukacyjnych w kształtowaniu kwalifikacji i umiejętności. Dodatkowo uwzględnia się wpływ usług medycznych. Na funkcjonowanie obsługi biznesu duży wpływ będą miały usługi profesjonalne, takie jak np. doradztwo, marketing czy obsługa prawna i księgowa. Kapitał finansowy natomiast analizuje się z perspektywy usług instytucji zapewniających jego dostępność, a więc zajmujących się udzielaniem preferencyjnych pożyczek, gwarancji kredytowych, a także innych usług finansowych. Kształtowanie właściwego klimatu działalności gospodarczej (klimat społeczny) jest domeną władz samorządowych i prowadzonej przez nie polityki, a także różnego rodzaju organizacji i stowarzyszeń wspierających rozwój.

Przedstawiony schemat uwzględniający wydzielone kategorie czynników (środowisko innowacyjne, obsługa biznesu, kapitał ludzki, klimat społeczny oraz kapitał finansowy) ma jednak postać znacznie uproszczoną, bowiem pomiędzy tymi kategoriami także zachodzi sieć wzajemnych relacji. Przykładem może być środowisko innowacyjne, którego funkcjonowanie w dużej mierze zależne jest od kapitału finansowego (Dominiak, Churski, 2012), kapitału ludzkiego i klimatu społecznego. Na funkcjonowanie tego 
środowiska wpływ ma także poziom rozwoju usług profesjonalnych (np. informatycznych, marketingowych, doradczych). W taki sam sposób można analizować zależności pomiędzy pozostałymi elementami schematu. Podstawowe jednak znaczenie - z punktu widzenia celu niniejszej analizy - ma wpływ wyróżnionych nowoczesnych usług na kształtowanie się nowoczesnej gospodarki opartej na wiedzy poprzez oddziaływanie na główne kategorie czynników jej rozwoju.

Należy także zwrócić uwagę, że wyróżnione nowoczesne usługi mają wpływ na kształtowanie się nie tylko jednej, przyporządkowanej im w schemacie, kategorii czynników. Na przykład usługi edukacyjne mają wpływ nie tylko na kształtowanie się kapitału ludzkiego, ale również na pozostałe kategorie czynników - poprzez kształtowanie odpowiednich zasobów pracy dla środowiska innowacyjnego, obsługi biznesu, usług finansowych. Podobnie usługi profesjonalne i finansowe niezbędne są także dla właściwego funkcjonowania środowiska innowacyjnego, kształtowania odpowiedniego klimatu działalności gospodarczej. Także działalność władz samorządowych można rozpatrywać w kontekście nie tylko kształtowania klimatu gospodarczego, ale także kształtowania kapitału ludzkiego i społecznego czy prowadzonej strategii innowacyjnej. Przedstawiony schemat cechuje się więc dużym stopniem generalizacji i w bardzo uproszczony sposób pokazuje najważniejsze relacje zachodzące pomiędzy analizowanymi elementami.

Wszystkie wymienione wcześniej czynniki rozwoju GOW cechuje głęboka współzależność. Relacje te obejmują zarówno sferę nauki odpowiedzialną za generowanie innowacji, jak i wdrażającą je sferę gospodarki oraz wspomagające oba te procesy organizacje i władze samorządowe. Do relacji tych nawiązuje koncepcja potrójnej Helisy (Etzkowitz, Leydesdorff, 1995), w której współpraca między sferą nauki, gospodarki i władz publicznych ma prowadzić do najbardziej optymalnych warunków rozwoju.

\section{WERYFIKACJA EMPIRYCZNA MODELU}

Kolejnym etapem postępowania badawczego była próba weryfikacji empirycznej skonstruowanego modelu w układzie wybranych państw Unii Europejskiej w 2014 roku. W tym celu w pierwszym kroku zebrano zbiór cech opisujących poziom rozwoju wyróżnionych wcześniej nowoczesnych usług (usługi input). Wykorzystano mierniki poziomu rozwoju tych usług, w tym dostępności placówek usługowych, ich finansowania oraz zatrudnionego personelu. Ze względu na ograniczenia w dostępności do danych statystycznych w weryfikacji empirycznej skonstruowanego modelu nie uwzględniono czynnika kapitał społeczny i usług związanych z jego kształtowaniem. Listę wykorzystanych wskaźników zawiera tab. 2.

W analizie zróżnicowania przestrzennego poziomu rozwoju nowoczesnych usług zastosowano syntetyczny wskaźnik Perkala² w następującej postaci (Runge, 2007: 214):

gdzie

$$
W_{s}=\frac{\sum_{j=1}^{p} y_{i j}}{p}
$$

Ws - wskaźnik syntetyczny

$j-1,2, \ldots, \mathrm{p}$

$p$ - liczba uwzględnionych cech,

$y_{i j}$ - standaryzowana wartość $j$-tej cechy dla $i$-tego obiektu

${ }^{2}$ Wskaźnik Perkala do oceny potencjału innowacyjnego województw wykorzystali m.in. A. Nowakowska, M. Feltynowski (2009: 11-24). 
Tab. 2. Wskaźniki poziomu rozwoju nowoczesnych usług

\begin{tabular}{|c|c|c|}
\hline Rodzaj usług & Wskaźniki - usługi input & $\begin{array}{l}\text { Wskaźniki - usługi output (czynniki } \\
\text { rozwoju) }\end{array}$ \\
\hline \multirow{8}{*}{ Edukacja } & Usługi edukacyjne & Kapitał ludzki I \\
\hline & $\begin{array}{l}\text { Odsetek nauczycieli w aktywnych } \\
\text { zawodowo }\end{array}$ & Wskaźnik aktywności zawodowej \\
\hline & Wydatki na edukację jako \% PKB & Odsetek osób z wykształceniem wyższym \\
\hline & Wskaźnik skolaryzacji & \multirow{5}{*}{$\begin{array}{l}\text { Odsetek inżynierów i naukowców } \\
\text { w aktywnych zawodowo }\end{array}$} \\
\hline & $\begin{array}{l}\text { Odsetek studentów kierunków } \\
\text { technicznych }\end{array}$ & \\
\hline & $\begin{array}{l}\text { Odsetek osób powyżej } 25 \text { roku życia } \\
\text { biorących udział w kształceniu (LL) }\end{array}$ & \\
\hline & $\begin{array}{l}\text { Odsetek pracujących w sekcji: } \\
\text { edukacja }\end{array}$ & \\
\hline & $\begin{array}{l}\text { Odsetek osób korzystających } \\
\text { z e-learningu }\end{array}$ & \\
\hline \multirow{4}{*}{ Medycyna } & Usługi medyczne & Kapitał ludzki II \\
\hline & $\begin{array}{l}\text { Personel medyczny na } 100 \text { tys. } \\
\text { mieszkańców }\end{array}$ & Przeciętna długość życia kobiet/mężczyzn \\
\hline & $\begin{array}{l}\text { Wydatki na ochronę zdrowia na } \\
\text { jednego mieszkańca (euro) }\end{array}$ & \multirow{2}{*}{$\begin{array}{l}\text { Liczba lat przeżytych w zdrowiu kobiety/ } \\
\text { mężczyźni }\end{array}$} \\
\hline & $\begin{array}{l}\text { Odsetek pracujących w sekcji: ochrona } \\
\text { zdrowia i opieka społeczna }\end{array}$ & \\
\hline \multirow{4}{*}{$\begin{array}{l}\text { Działalność } \\
\text { badawczo- } \\
\text {-rozwojowa }\end{array}$} & Usługi badawczo-rozwojowe & Innowacyjność \\
\hline & $\begin{array}{l}\text { GERD - wydatki ogółem na B + R na } \\
1 \text { mieszkańca (euro) }\end{array}$ & Udział obrotu z innowacji \\
\hline & $\begin{array}{l}\text { BERD - wydatki przedsiębiorstw na } \\
\text { B + R na } 1 \text { mieszkańca (euro) }\end{array}$ & Odsetek przedsiębiorstw innowacyjnych \\
\hline & $\begin{array}{l}\text { Odsetek pracujących w B + R } \\
\text { w aktywnych zawodowo }\end{array}$ & Patenty na 1 mln mieszkańców \\
\hline \multirow{4}{*}{ Finanse } & Usługi finansowe & Kapitał finansowy \\
\hline & $\begin{array}{l}\text { Odsetek pracujących w sekcji: } \\
\text { pośrednictwo finansowe }\end{array}$ & $\begin{array}{l}\text { Wartość dodana brutto na jednego } \\
\text { zatrudnionego w przedsiębiorstwach }\end{array}$ \\
\hline & $\begin{array}{l}\text { Liczba instytucji kredytowych na } 1 \text { tys. } \\
\text { podmiotów gospodarczych }\end{array}$ & $\begin{array}{l}\text { Inwestycje na jednego zatrudnionego } \\
\text { w przedsiębiorstwach }\end{array}$ \\
\hline & $\begin{array}{l}\text { Odsetek zatrudnionych w instytucjach } \\
\text { kredytowych }\end{array}$ & \\
\hline \multirow{3}{*}{ Obsługa biznesu } & Usługi profesjonalne & Środowisko sprzyjające biznesowi \\
\hline & Odsetek pracujących w sektorze ICT & $\begin{array}{l}\text { Odsetek osób nowo zatrudnionych } \\
\text { w ogólnym zatrudnieniu }\end{array}$ \\
\hline & $\begin{array}{l}\text { Odsetek zatrudnionych w usługach } \\
\text { profesjonalnych (sekcja M) }\end{array}$ & $\begin{array}{l}\text { Liczba podmiotów gospodarczych na } 1 \text { tys. } \\
\text { mieszkańców }\end{array}$ \\
\hline
\end{tabular}

Źródło: opracowanie własne

Zastosowanie wskaźnika syntetycznego wymagało w pierwszej kolejności standaryzacji wartości wskaźników opisujących natężenie poszczególnych cech. Standaryzację dla cech mających charakter stymulant przeprowadzono w oparciu o formułę:

$$
y_{i j}=\frac{x_{i j}-\bar{x}}{S_{j}}
$$


gdzie:

$y_{i j}$ - standaryzowana wartość $j$-tej cechy dla $i$-tego obiektu

$x_{i j}$ - wartość $j$-tej cechy dla $i$-tego obiektu

$\bar{X}$ - średnia arytmetyczna wartości $j$-tej cechy

$S_{j}$ - odchylenie standardowe wartości $j$-tej cechy

Standaryzacja wartości wskaźników doprowadziła do uzyskania macierzy zmiennych standaryzowanych, które wykorzystano przy obliczaniu wskaźników syntetycznych (WS) dla 2014 roku. Na podstawie rozpiętości wartości wskaźników syntetycznych określono skalę zróżnicowania występującego w poziomie rozwoju nowoczesnych usług w wybranych państwach europejskich.

W analizie zróżnicowania przestrzennego poziomu rozwoju nowoczesnych usług w wybranych państwach Europy zastosowano wskaźnik sumaryczny poziomu rozwoju nowoczesnych usług (WS) oraz wskaźniki cząstkowe (WC1, WC2, WC3, WC4, WC5) odpowiadające pięciu wyróżnionym rodzajom nowoczesnych usług: edukacyjnych, medycznych, badawczo-rozwojowych, profesjonalnych (dla biznesu) i finansowych. Wyniki klasyfikacji państw europejskich według wartości wskaźnika syntetycznego poziomu rozwoju usług nowoczesnych prezentuje kartogram (ryc. 2) i tab. 3. Najwyższy poziom rozwoju usług nowoczesnych cechuje państwa skandynawskie: Szwecję, Finlandię i Danię oraz Luksemburg. Wysokie wartości wskaźnika syntetycznego odnotowano także w Belgii, Holandii, Austrii, Niemczech oraz Irlandii. 0 wysokiej pozycji państw skandynawskich zadecydował wysoki poziom rozwoju usług badawczo-rozwojowych, edukacyjnych i usług dla biznesu. Niemcy i Austria natomiast cechują się wysokim poziomem

Ryc. 2. Poziom rozwoju usług nowoczesnych w krajach UE w 2014 roku

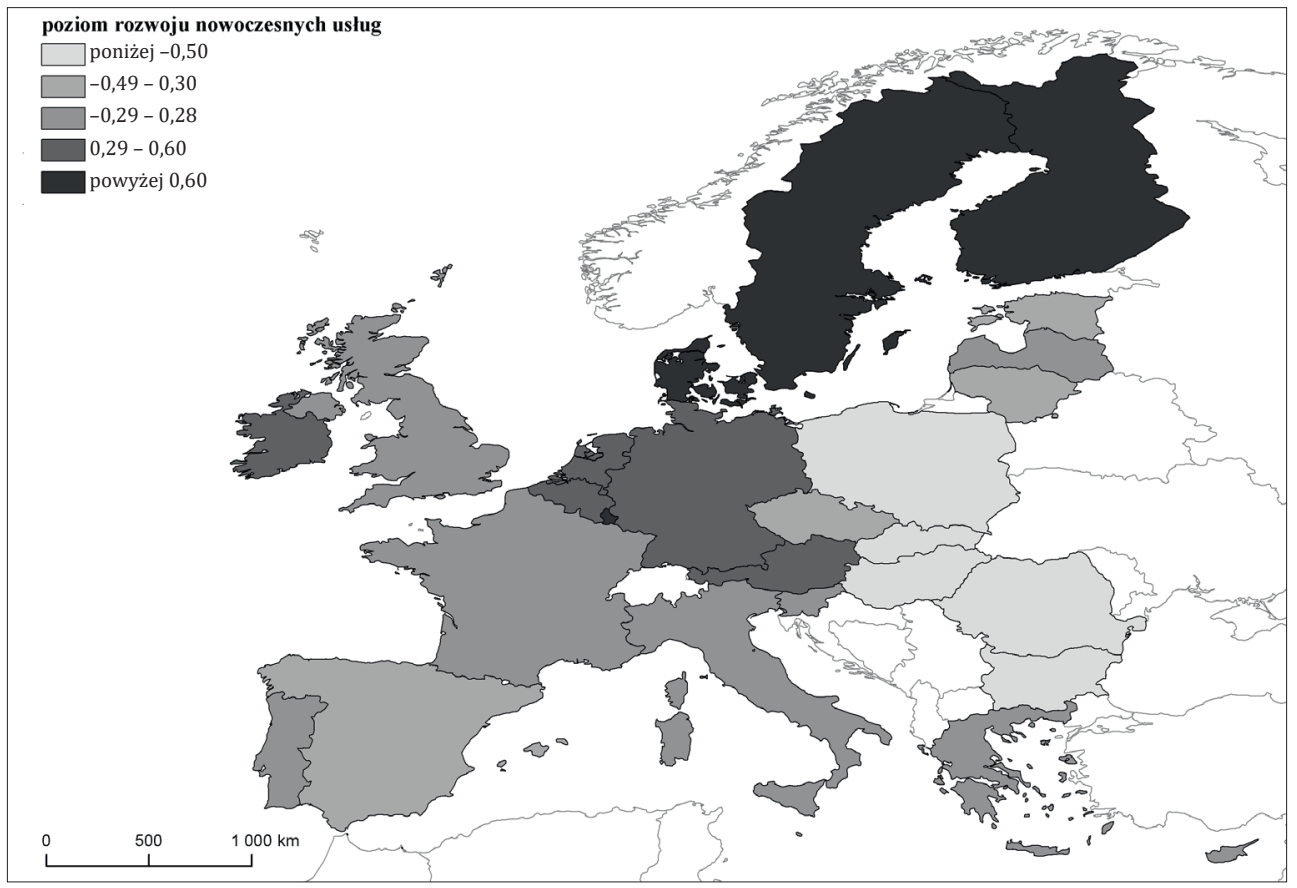

Źródło: opracowanie własne na podstawie danych z bazy Eurostatu 
rozwoju usług medycznych. Niekwestionowanym liderem w zakresie poziomu rozwoju usług finansowych jest Luksemburg. Najniższy poziom rozwoju nowoczesnych usług charakteryzuje państwa Europy Środkowo-Wschodniej - Rumunię, Bułgarię oraz Polskę, Węgry i Słowację (ryc. 3).

Tab. 3. Państwa o najwyższym i najniższym poziomie rozwoju wybranych usług nowoczesnych

\begin{tabular}{|c|c|c|c|c|c|}
\hline & $\begin{array}{c}\text { Usługi } \\
\text { edukacyjne }\end{array}$ & Usługi medyczne & $\begin{array}{c}\text { Usługi badawczo- } \\
\text {-rozwojowe }\end{array}$ & Usługi finansowe & $\begin{array}{c}\text { Usługi dla } \\
\text { biznesu }\end{array}$ \\
\hline $\begin{array}{l}\text { Najwyższy } \\
\text { poziom rozwoju }\end{array}$ & $\begin{array}{l}\text { - Szwecja } \\
\text { - Dania } \\
\text { - Finlandia }\end{array}$ & $\begin{array}{l}\text { - Szwecja } \\
\text { - Austria } \\
\text { - Niemcy }\end{array}$ & $\begin{array}{l}\text { - Dania } \\
\text { - Szwecja } \\
\text { - Finlandia } \\
\text { - Austria }\end{array}$ & - Luksemburg & $\begin{array}{l}\text { - Szwecja } \\
\text { - Finlandia } \\
\text { - Wielka } \\
\quad \text { Brytania } \\
\end{array}$ \\
\hline $\begin{array}{l}\text { Najniższy } \\
\text { poziom rozwoju }\end{array}$ & $\begin{array}{l}\text { - Słowacja } \\
\text { - Rumunia } \\
\text { - Bułgaria }\end{array}$ & $\begin{array}{l}\text { - Węgry } \\
\text { - Rumunia } \\
\text { - Polska }\end{array}$ & $\begin{array}{l}\text { - Polska } \\
\text { - Cypr } \\
\text { - Bułgaria } \\
\text { - Rumunia }\end{array}$ & $\begin{array}{l}\text { - Słowacja } \\
\text { - Estonia } \\
\text { - Litwa } \\
\text { - Rumunia }\end{array}$ & $\begin{array}{l}\text { - Słowacja } \\
\text { - Polska } \\
\text { - Litwa } \\
\text { - Rumunia }\end{array}$ \\
\hline
\end{tabular}

Źródło: opracowanie własne na podstawie danych z bazy Eurostatu

Ryc. 3. Poziom rozwoju usług nowoczesnych w wybranych krajach UE w 2014 roku

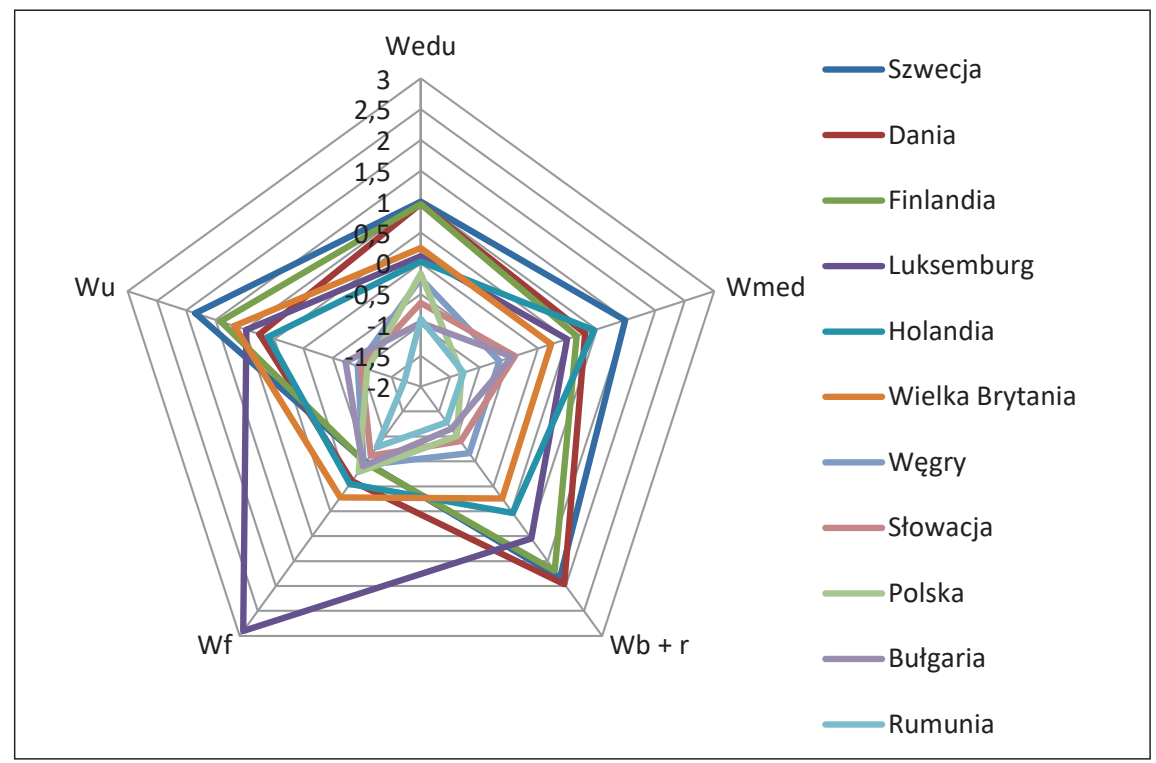

Wedu - usługi edukacyjne, Wmed - usługi medyczne, Wb + r - usługi badawczo-rozwojowe, Wf - usługi finansowe, $\mathrm{Wu}$ - usługi dla biznesu

Źródło: opracowanie własne na podstawie danych z bazy Eurostatu

W drugim kroku podobną procedurę zastosowano w odniesieniu do cech opisujących czynniki rozwoju (usługi output) (tab. 1). Na końcowym etapie postępowania badawczego wyniki te zestawiono z syntetycznym wskaźnikiem poziomu rozwoju nowoczesnej gospodarki, obliczonym przy wykorzystaniu trzech cech: udziału pracujących w htm (high technology manufacturing) w ogólnym zatrudnieniu (\%), udziału eksportu high tech w eksporcie ogółem (\%), produktu krajowego brutto na 1 mieszkańca. Wartość wspołczynników korelacji pomiędzy poziomem rozwoju poszczególnych rodzajów 
Ryc. 4. Wartości współczynników korelacji

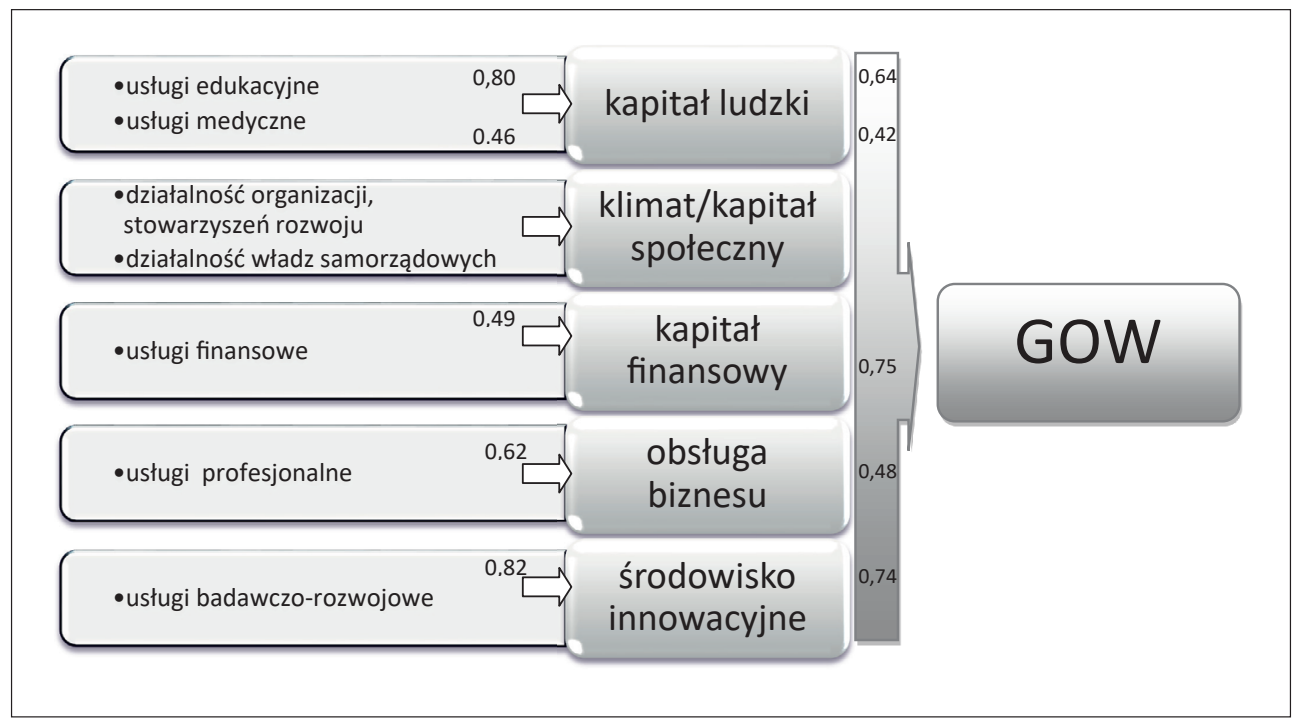

Źródło: opracowanie własne na podstawie danych z bazy Eurostatu

nowoczesnych usług a wyróżnionymi czynnikami rozwoju przedstawiono na ryc. 4. Wszystkie obliczone wskaźniki korelacji były istotne statystycznie (poziom istotności kształtował się poniżej 0,05), a ich wartości świadczą o dodatniej zależności pomiędzy nowoczesnymi usługami a czynnikami rozwoju nowoczesnej gospodarki oraz między analizowanymi czynnikami a poziomem rozwoju gospodarczego.

\section{PoDSUMOWANIE}

Przeprowadzona analiza prowadzi do następujących wniosków:

1. Najwyższym poziomem rozwoju nowoczesnych usług cechują się państwa skandynawskie, a także Niemcy, Austria, Irlandia i kraje Beneluxu. Podobnym rozkładem cechuje się także poziom rozwoju nowoczesnej gospodarki (mierzony wartością wskaźnika syntetycznego). Szwecja, Finlandia i Dania cechują się zdecydowanie najwyższym poziomem rozwoju usług edukacyjnych i badawczo-rozwojowych. Państwa o najwyższym poziomie rozwoju usług medycznych to obok państw Skandynawii Niemcy i Austria, a usług dla biznesu - Wielka Brytania. Niekwestionowanym liderem rozwoju usług finansowych jest Luksemburg.

2. Weryfikacja skonstruowanego modelu wpływu nowoczesnych usług na rozwój gospodarczy prowadzi do wniosku, że wśród najważniejszych czynników rozwoju nowoczesnej gospodarki są: działalność innowacyjna i kapitał materialny. Ważną rolę odgrywa także kapitał ludzki (szczególnie w sferze edukacji).

3. Wyniki analizy empirycznej potwierdzają założenia o silnym wpływie nowoczesnych usług na rozwój gospodarczy. Szczególną rolę odgrywają tu usługi sektora B + R (poprzez kształtowanie innowacyjności) oraz usługi finansowe zapewniające dostęp do kapitału finansowego, niezbędnego w procesie rozwoju. Analiza korelacji potwierdza także duże znaczenie usług edukacyjnych w kształtowaniu kapitału ludzkiego, a przez to także rozwoju gospodarczego. 


\section{Literatura \\ References}

Archibugi, D., Howells, J., Michie, J. (1999). Innovation Systems in the Global Economy. Cambridge: Cambridge University Press.

Aydalot, P., Keeble, D. (1988). High technology industry and innovative environments: The European experience. London: Routledge.

Baron, S., Field, J., Schuller, T. (2002). Social capital. Critical perspectives. Oxford: University Press.

Becker, G.S. (1993). Human Capital: A Theoretical and Empirical Analysis, with Special Reference to Education. Chicago: University of Chicago Press.

Berger, A.N., Udell, G.F. (2002). Small business credit availability and relationship lending: the importance of bank organizational structure. Economic Journal, 112, 32-53.

Camagni, R. (1991). Local "Milieu", Uncertainty and Innovation Networks: Towards a New Dynamic Theory of Economic Space. W: R. Camagni (red.). Innovation Networks: Spatial Perspectives. London: BelhavenPinter, 121-144.

Capello, R., Nijkamp, P. (red.) (2009). Regional growth and development theories in the XXI Century. Cheltenham: Edwar Elgar.

Chojnicki, Z., Czyż, T. (2003). Poland on the road to a knowledge-based economy: a regional approach. W: R. Domański (red.). Recent advances in urban and regional studies. Studia Regionalia, 12, 199-213.

Chojnicki, Z., Czyż, T. (2006). Aspekty regionalne gospodarki opartej na wiedzy w Polsce. Poznań: Bogucki Wydawnictwa Naukowe.

Churski, P. (2008). Czynniki rozwoju regionalnego i polityka regionalna w Polsce w okresie integracji z Uniq Europejską. Poznań: Wydawnictwo Naukowe UAM.

Coffey, W. (2000). The Geographies of Producer Services. Urban Geography, 21(2), 170-183.

Coleman, J.S. (1990). Foundations of social theory. Cambridge: Belknap Press of Harvard University Press.

Colombo, M.G., Grilli, L., Piscitello, L., Rossi-Lamastra, C. (2011). Science and innovation policy for the new knowledge economy. Cheltenham: Edward Elgar Publishing.

Domański, S.R. (1993). Kapitał ludzki i wzrost gospodarczy. Warszawa: Wydawnictwo Naukowe PWN.

Dominiak, J. (2006). Struktura i organizacja otoczenia biznesu w aglomeracji poznańskiej. Poznań: Bogucki Wydawnictwo Naukowe.

Dominiak, J., Churski, P. (2012). Rola innowacji w kształtowaniu regionów wzrostu i stagnacji gospodarczej w Polsce. Studia Regionalne i Lokalne, 4, 54-77.

Drucker, P. (1993). Post-Capitalist Society. Oxford: Butterworth Heinemann.

Eichengreen, B., Gupta, P. (2009). The two waves of service sector growth. NBER Working Papers Series, 14968.

Etzkowitz, H., Leydesdorff, L. (1995). The Triple Helix: University-Industry-Government Relations: A Laboratory for Knowledge-Based Economic Development. EASST Review, 14, 14-19.

Fagerberg, J., Mowery, D.C., Nelson R.R. (red.) (2004). Oxford Handbook of Innovation. Oxford: Oxford University Press.

Feldman, M., Link, A. (red.) (2001). Innovation policy in the knowledge-based economy. Dordrecht: Kluwer.

Flejterski, S., Panasiuk, A., Perenc, J., Rosa, G. (2005). Współczesna ekonomika usług. Warszawa: Wydawnictwo Naukowe.

Freeman, Ch., Soete, L. (2009). Developing science, technology and innovation indicators: What we can learn from the past. Research Policy, 38(4), 583-589.

Fukuyama, F. (1999) (2016, 17 grudnia). Social capital and civil society. IMF Conference on Second Generation Reforms. Pozyskano z http://www.imf.org/external/pubs/ft/seminar/1999/reforms/ fukuyama.htm

Illeris, S. (1996). The Service Economy: A Geographical Approach. Chichester: Wiley. 
Ilnicki, D. (2009). Przestrzenne zróżnicowanie poziomu rozwoju usług w Polsce. Teoretyczne i praktyczne uwarunkowania badań. Rozprawy Naukowe Instytutu Geografii i Rozwoju Regionalnego Uniwersytetu Wrocławskiego, 11.

Jakubowicz, E. (2000). Rola usług „nowych” w przekształceniach systemu miast regionu dolnoślaskiego. W: J. Słodczyk (red.). Społeczne, gospodarcze i przestrzenne przeobrażenia miast. Opole: Uniwersytet Opolski, 177-186.

Jewtuchowicz, A. (1996). Powstawanie środowiska i sieci innowacji. Teorie i rzeczywistość. W: K.B. Matusiak, K. Zasiadły, T. Broczkowski, M. Pietraszewski (red.). Ośrodki innowacji i przedsiębiorczości w Polsce. Poznań: Stowarzyszenie Organizatorów Ośrodków Innowacji i Przedsiębiorczości, 59-74.

Katouzian, M.A. (1970). The Development of the Service Sector: A New Approach. Oxford Economic Papers, 22, 362-382.

Keeble, D., Lawson, C., Moore, B., Wilkinson, F. (1999). Collective learning processes, networking and institutional thickness in Cambridge region. Regional Studies, 33(4), 319-332.

Kłosiński, K. (2000). Zmiany w strukturze wytwarzania usług rynkowych w latach 1990-1998. W: A. Lipowski (red.). Struktura gospodarki transformującej się. Polska 1990-1998 i projekcja do 2010. Warszawa: Polska Akademia Nauk, 175-209.

Komorowski, J. (2010). Kapitał ludzki i społeczny a zróżnicowanie innowacyjności gospodarki w podregionach Wielkopolski. Studia Oeconomica Posnaniensia, 131, 62-80.

Lin, N. (2001). Social capital. A theory of social structure and action. Cambridge: Cambridge University Press.

Longhi, C. (1999). Networks, collective learning and technology development in innovative high technology regions: The case of Sophia-Antipolis. Regional Studies, 33(4), 333-342.

Lundvall, B.A. (2000). Gospodarka ucząca się: Pewne implikacje dla bazy wiedzy o systemie ochrony zdrowia i edukacji. W: Zarzq̨dzanie wiedza w społeczeństwie uczącym się. Centrum Badań nad Edukacją i Innowacją OECD. Warszawa: Ministerstwo Gospodarki. Departament Strategii Gospodarczej, 117-133.

Lundvall, B., Johnson, B. (1994). The Learning Economy. Journal of Industry Studies, 1(2).

Markowski, T., Drzazga, D. (2008). Rola wyższych uczelni w rozwoju społeczno-gospodarczym i przestrzennym miast. Warszawa: Komitet Przestrzennego Zagospodarowania Kraju Polskiej Akademii Nauk.

Nowakowska, A., Feltynowski, M. (2009). Metoda oceny potencjału innowacyjnego regionów. W: A. Nowakowska (red.). Zdolności innowacyjne polskich regionów, 11-24.

Pakulska, T. (2005). Podatność innowacyjna Polski na napływ zagranicznego kapitału technologicznie intensywnego. Warszawa: Szkoła Główna Handlowa.

Pavitt, K. (2005). Innovation Processes. W: J. Fagerberg, D. Mowery, R. Nelson (red.). The Oxford Handbook of Innovation. Oxford: Oxford University Press, 86-114.

Piech, K. (2009). Wiedza i innowacje w rozwoju gospodarczym: $w$ kierunku pomiaru i współczesnej roli państwa. Warszawa: Instytut Wiedzy i Innowacji.

Pietrzyk, I. (2001). Polityka regionalna Unii Europejskiej i regiony w państwach członkowskich. Warszawa: Wydawnictwo Naukowe PWN.

Putnam, R. (1993). Making democracy work: civic traditions in modern Italy. Princeton, New Jork: Princeton University Press.

Runge, J. (2007). Metody badań w geografii społeczno-ekonomicznej - elementy metodologii, wybrane narzędzia badawcze. Katowice: Wydawnictwo Uniwersytetu Śląskiego.

Stone, W., Hughes, J. (2000) (2016, 17 grudnia). What role for social capital in family and how does it measure up? Family futures: Issues in research and policy. Australian Institute of Family Studies Conference. Pozyskano z http://aifs.gov.au/conferences/aifs7/stone.pdf

Uppenberg, K. (2009). Innovation and economic growth. EIB Papers, 14(1).

Werwicki, A. (1998). Zmiany paradygmatu geografii usług. Przegląd Geograficzny, 70, 3-4. 
Joanna Dominiak, dr, adiunkt w Zakładzie Analizy Regionalnej Instytutu Geografii Społeczno-Ekonomicznej i Gospodarki Przestrzennej Uniwersytetu im. Adama Mickiewicza w Poznaniu. Zainteresowania naukowe koncentrują się wokół roli innowacyjności w kształtowaniu gospodarki opartej na wiedzy, wpływu otoczenia biznesu na rozwój regionów oraz przemian w strukturze usług.

Joanna Dominiak, Ph.D., assistant professor in the establishment of the Regional Analysis Department in the Institute of Socio-Economic Geography and Spatial Management of Adam Mickiewicz University in Poznan. Her academic interests revolve around the role of innovation in the development of the knowledge-based economy, the impact of the business environment on the development of regions and changes in the structure of services.

\section{Adres/address:}

Uniwersytet im. A. Mickiewicza w Poznaniu Instytut Geografii Społeczno-Ekonomicznej i Gospodarki Przestrzennej Zakład Analizy Regionalnej Instytutu Geografii Społeczno-Ekonomicznej i Gospodarki Przestrzennej ul. Dzięgielowa 27, 61-680 Poznań, Polska

e-mail:dominiak@amu.edu.pl 